Two Decision-Support Tools for Assessing the Potential Effects of Energy Development on Hydrologic Resources as Part of the Energy and Environment in the Rocky Mountain Area Interactive Energy Atlas

By Joshua I. Linard, Anne Marie Matherne, Kenneth J. Leib, Natasha B. Carr, James E. Diffendorfer, Sarah J. Hawkins, Natalie Latysh, Drew A. Ignizio, and Nils C. Babel

Open-File Report 2014-1158

U.S. Department of the Interior

U.S. Geological Survey 


\section{U.S. Department of the Interior \\ SALLY JEWELL, Secretary}

\section{U.S. Geological Survey \\ Suzette M. Kimball, Acting Director}

U.S. Geological Survey, Reston, Virginia: 2014

For more information on the USGS-the Federal source for science about the Earth,

its natural and living resources, natural hazards, and the environment-visit

http://www.usgs.gov or call 1-888-ASK-USGS

For an overview of USGS information products, including maps, imagery, and publications,

visit $h$ ttp://www.usgs.gov/pubprod

To order this and other USGS information products, visit $h$ ttp://store.usgs.gov

Suggested citation:

Linard, J.I., Matherne, Anne Marie, Leib, K.J., Carr, N.B., Diffendorfer, J.E., Hawkins, S.J., Latysh, Natalie, Ignizio, D.A., and Babel, N.C., 2014, Two decision-support tools for assessing the potential effects of energy development on hydrologic resources as part of the Energy and Environment in the Rocky Mountain Area interactive energy atlas: U.S. Geological Survey Open-File Report 2014-1158, 16 p., http://dx.doi.org/10.3133/ofr20141158.

ISSN 2331-1258 (online)

Any use of trade, firm, or product names is for descriptive purposes only and does not imply endorsement by the U.S. Government.

Although this information product, for the most part, is in the public domain, it also may contain copyrighted materials as noted in the text. Permission to reproduce copyrighted items must be secured from the copyright owner. 


\section{Contents}

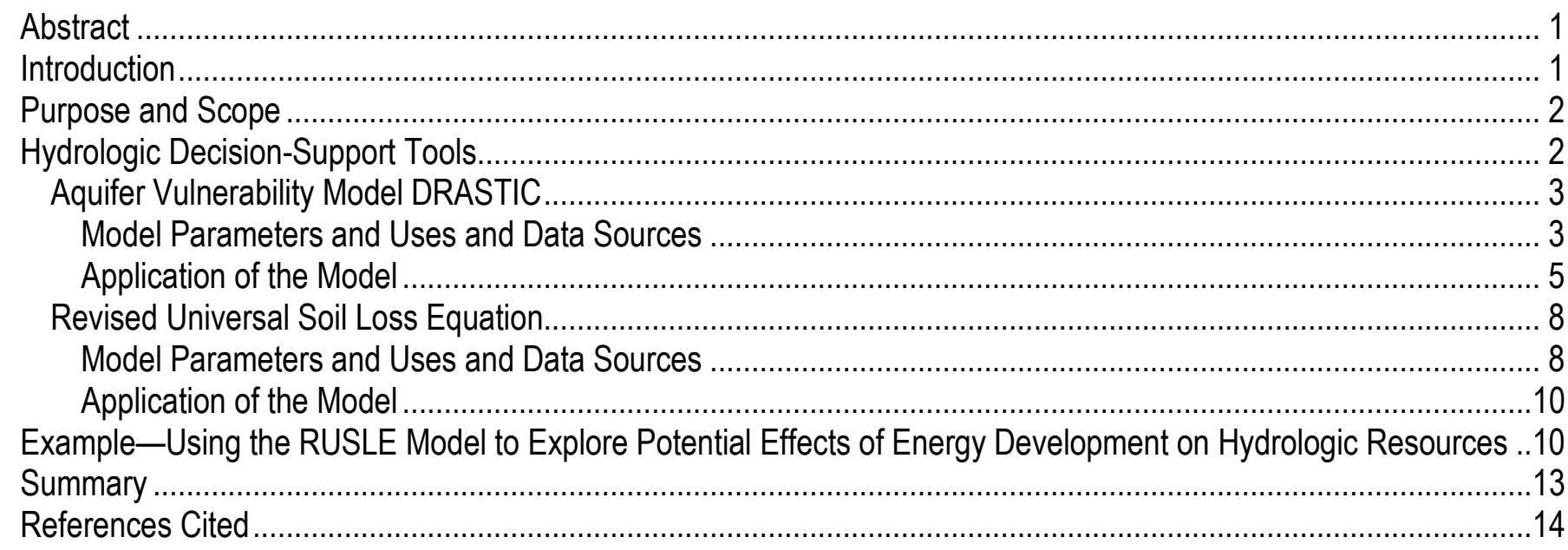

\section{Figures}

Figure 1. Aquifer vulnerability for Colorado and New Mexico as estimated by using the index value from $d$ epth to water, recharge, aquifer media, soil media, topography, impact of the vadose zone, and hydraulic conductivity of the aquifer (DRASTIC)

Figure 2. Potential mean annual erosion for Colorado and New Mexico as estimated by using the revised universal soil loss equation (RUSLE)

Figure 3. Examples of the use of the revised universal soil loss equation (RUSLE) model as a hydrologic decisionsupport tool, comparing three landscape features under three scenarios of vegetative cover $(C)$ and four scenarios of erosion-control practice $(P)$. $A$, Hypothetical study area including representative surface features. $B$, Generalized topography for the hypothetical study area. $C$, Relative changes in erosion potential for three types of surface features under four land-surface conditions. As the $C$ or $P$ value increases, model cells for which relative erosion potential increases are shown by a change in cell color

\section{Table}

Table 1. Recharge $(R)$ values assigned to national land cover dataset (Vogelmann, 2001) land-use classifications... 4 


\section{Conversion Factors}

Inch/Pound to SI

\begin{tabular}{lll}
\hline & \multicolumn{1}{c}{ Multiply } & \multicolumn{1}{c}{ To obtain } \\
\hline foot $(\mathrm{ft})$ & Length & \\
mile $(\mathrm{mi})$ & 0.3048 & meter $(\mathrm{m})$ \\
\hline & 1.609 & kilometer $(\mathrm{km})$ \\
\hline acre & Area & \\
acre & 4,047 & square meter $\left(\mathrm{m}^{2}\right)$ \\
acre & 0.4047 & hectare $($ ha) \\
square mile $\left(\mathrm{mi}{ }^{2}\right)$ & 0.004047 & square kilometer $\left(\mathrm{km}^{2}\right)$ \\
\hline & 2.590 & square kilometer $\left(\mathrm{km}^{2}\right)$ \\
\hline ton per year $(\mathrm{ton} / \mathrm{yr})$ & Mass & \\
ton per year $(\mathrm{ton} / \mathrm{yr})$ & 0.9072 & megagram $(\mathrm{Mg} / \mathrm{yr})$ \\
\hline
\end{tabular}

SI to Inch/Pound

\begin{tabular}{lcl}
\hline & Multiply & \\
\hline & Length & To obtain \\
\hline meter $(\mathrm{m})$ & 0.6214 & mile $(\mathrm{mi})$ \\
\hline & Area & \\
\hline hectare (ha) & 2.471 & acre \\
hectare (ha) & 0.003861 & square mile $\left(\mathrm{mi}^{2}\right)$ \\
\hline & Mass & \\
\hline ton per hectare per year & 17.02 & tons per acre per year \\
\hline
\end{tabular}

\section{Abbreviations}

DEM digital elevation model

DRASTIC depth to water, recharge, aquifer media, soil media, topography, impact of the vadose zone, and hydraulic conductivity of the aquifer

EERMA Energy and Environment in the Rocky Mountain Area

GIS geographic information system

NLCD national land cover dataset

RUSLE revised universal soil loss equation

STATSGO State Soil Geographic 


\title{
Two Decision-Support Tools for Assessing the Potential Effects of Energy Development on Hydrologic Resources as Part of the Energy and Environment in the Rocky Mountain Area Interactive Energy Atlas
}

By Joshua I. Linard, Anne Marie Matherne, Kenneth J. Leib, Natasha B. Carr, James E. Diffendorfer, Sarah J. Hawkins, Natalie Latysh, Drew A. Ignizio, and Nils C. Babel

\begin{abstract}
The U.S. Geological Survey project-Energy and Environment in the Rocky Mountain Area (EERMA) - has developed a set of virtual tools in the form of an online interactive energy atlas for Colorado and New Mexico to facilitate access to geospatial data related to energy resources, energy infrastructure, and natural resources that may be affected by energy development. The interactive energy atlas currently (2014) consists of three components: (1) a series of interactive maps; (2) downloadable geospatial datasets; and (3) decison-support tools, including two maps related to hydrologic resources discussed in this report. The hydrologic-resource maps can be used to examine the potential effects of energy development on hydrologic resources with respect to (1) groundwater vulnerability, by using the $d$ epth to water, recharge, aquifer media, soil media, topography, $i$ mpact of the vadose zone, and hydraulic conductivity of the aquifer (DRASTIC) model, and (2) landscape erosion potential, by using the revised universal soil loss equation (RUSLE).

The DRASTIC aquifer vulnerability index value for the two-State area ranges from 48 to 199. Higher values, indicating greater relative aquifer vulnerability, are centered in south-central Colorado, areas in southeastern New Mexico, and along riparian corridors in both States - all areas where the water table is relatively close to the land surface and the aquifer is more susceptible to surface influences. As calculated by the RUSLE model, potential mean annual erosion, as soil loss in units of tons per acre per year, ranges from 0 to 12,576 over the two-State area. The RUSLE model calculated low erosion potential over most of Colorado and New Mexico, with predictions of highest erosion potential largely confined to areas of mountains or escarpments. An example is presented of how a fully interactive RUSLE model could be further used as a decision-support tool to evaluate the potential hydrologic effects of energy development on a site-specific basis and to explore the effectiveness of various mitigation practices.
\end{abstract}

\section{Introduction}

Increased demand for energy is driving rapid development of energy sources throughout the Western United States, including oil and gas, uranium, geothermal, wind, and solar energy. Much of the energy development is occurring on public lands, which represent about 40 percent of land ownership in Colorado and New Mexico (Copeland and others, 2011). The economies of Colorado and New Mexico benefit from the revenues produced by the development of their abundant energy resources (Headwaters Economics, 2012a,b). Resource managers and other decisionmakers must balance the benefits of energy 
development with the potential effects on hydrologic, recreational, ecological, and other resources. Although studies have assessed some effects of energy development (Gregory and others, 2011; Grubert and others, 2012; Loesch and others, 2012; and Warner and others, 2012; among others), much of the information is not synthesized to make it accessible and useful to decisionmakers, resource managers, and the general public. The U.S. Geological Survey project—Energy and Environment in the Rocky Mountain Area (EERMA) - has developed a set of virtual tools in the form of an online interactive energy atlas (Energy Atlas) for Colorado and New Mexico (http://my.usgs.gov/eerma/). The purpose of the Energy Atlas is to facilitate access to geospatial data related to energy resources, energy infrastructure, and natural resources that may be affected by energy development. The Energy Atlas can support decisionmakers and resource managers in their efforts to anticipate energy development scenarios in Colorado and New Mexico, evaluate the associated consequences, and develop appropriate mitigation strategies.

The Energy Atlas currently (2014) consists of three components: (1) a series of interactive maps; (2) downloadable geospatial datasets; and (3) decison-support tools, including the two maps related to hydrologic resources discussed in this report. The interactive maps display data related to oil and gas development, solar and wind development and resource potential, and a combined energy map that includes data from the three energy sources in a single map. Data used in creating the interactive maps in the Energy Atlas are presented as downloadable geographic information system (GIS) datasets. Supplementary physical and biological data, which may be used in exploring potential interactions among energy development and terrestrial and biological resources, are also included in the datasets. Along with the supplementary data, two maps are included as hydrologic decision-support tools that allow the user to explore the potential effects of energy development on hydrologic resources with respect to groundwater vulnerability and landscape erosion potential.

\section{Purpose and Scope}

The report presents two geospatial datasets - aquifer vulnerability and potential mean annual erosion-which are part of the Energy Atlas decision-support tools. The models on which the tools are based are briefly explained, as are datasets used in model development for the Colorado-New Mexico area. An example is presented of how a fully interactive tool could be used to evaluate the potential hydrologic effects of energy development on a site-specific basis and to explore the effectiveness of various mitigation practices.

\section{Hydrologic Decision-Support Tools}

The hydrologic decision-support tools in the Energy Atlas focus on groundwater and surfacewater quality. The potential effects of energy development on groundwater quality are explored by using (1) the aquifer vulnerability model: depth to water, recharge, aquifer media, soil media, topography, impact of the vadose zone, and hydraulic conductivity of the aquifer (DRASTIC; Aller and others, 1987); and (2) potential effects on surface-water quality are explored by using the revised universal soil loss equation (RUSLE) (Renard and others, 1997).

The aquifer vulnerability model DRASTIC was developed for the Colorado-New Mexico area to evaluate the susceptibility of shallow groundwater aquifers to influence by conservatively transported constituents that may be mobilized as a result of some types of energy development. Groundwater accounts for 19 percent of total water use in Colorado and 50 percent in New Mexico (Kenny and others, 2009). The potential effect of energy development on the quality of groundwater resources is, therefore, an important component in evaluating overall potential effects related to energy development. 
An assessment of groundwater vulnerability in an area is based on characterization of the susceptibility of the underlying aquifer to input from environmental or anthropogenic factors and is a function of the hydrogeologic setting (Hearne and others, 1995). Some types of energy development, such as solar and wind, occur on the land surface, whereas others, such as oil and gas, occur at depth but have surface components in the form of infrastructure development or the production of by-products. The DRASTIC assessment of aquifer vulnerability focuses on potential effects to the aquifer from development at the land surface.

RUSLE was used to map relative differences in erosion potential over the Colorado-New Mexico area. Energy development typically leads to changes in land cover, with the addition of roads, well pads, and other surface features as infrastructure to support development. Decreased land cover has been identified as a critical factor in increased sediment movement (Prosser and Williams, 1998; Nearing and others, 2005); mitigation strategies commonly focus on revegetation and stabilization of potentially vulnerable landscapes (Ren and others, 2011). Spatial analysis based on RUSLE (Renard and others, 1997) can be used as a decision-support tool to explore scenarios of development and mitigation. RUSLE does not address surface-water quality directly but points to areas of concern as potential sources of sediment input to waterways (Trahan, 2002), thus aiding in focusing management efforts.

\section{Aquifer Vulnerability Model DRASTIC}

\section{Model Parameters and Uses and Data Sources}

DRASTIC was developed by the U.S. Environmental Protection Agency and the National Water Well Association (Aller and others, 1985) as a methodology to systematically evaluate the vulnerability of the uppermost groundwater to input from sources at the land surface for any hydrogeologic setting throughout the United States. For an area of analysis, the model input parameters are represented geospatially. The physical data represented in each geospatial layer are assigned a unitless index value and a weight multiplier to indicate the importance of each type of data (Aller and others, 1987). The weighted sum of the layers is then calculated to achieve the aquifer vulnerability score or index, $D_{\mathrm{I}}$ :

$$
D_{\mathrm{I}}=D_{\mathrm{r}} D_{\mathrm{w}}+R_{\mathrm{r}} R_{\mathrm{w}}+A_{\mathrm{r}} A_{\mathrm{w}}+S_{\mathrm{r}} S_{\mathrm{w}}+T_{\mathrm{r}} T_{\mathrm{w}}+I_{\mathrm{r}} I_{\mathrm{w}}+C_{\mathrm{r}} C_{\mathrm{w}}
$$

where,

$D$ is depth to water,

$R$ is recharge,

$A$ is aquifer media,

$S$ is soil media,

$T$ is topography,

$I$ is impact of the vadose zone, and

$C$ is hydraulic conductivity of the aquifer.

The subscript $r$ refers to the index value (unitless) assigned to each type of geospatial data, and the subscript $w$ refers to the weight (unitless) assigned to each type of geospatial data. Higher index and weight values indicate greater relative aquifer vulnerability than lower index and weight values.

Since its development, DRASTIC has been extended to estimate aquifer vulnerability in a variety of environments throughout the world by using a geographic information system (GIS) (Shirazi and others, 2012), including urban (Rahman, 2008) and coastal (Voudouris and others, 2010) aquifers. Babiker and others (2005) created an integrated groundwater vulnerability map by combining a DRASTIC aquifer vulnerability map with potential pollution sources in central Japan.

DRASTIC methodologies and selected index and weighting values for both Colorado and New Mexico follow the DRASTIC model developed by the New Mexico Department of Agriculture (2012) 
for the State of New Mexico. The geospatial data representing depth to water were derived from the State of New Mexico Water Rights Reporting System (NMWRRS) database

(http://nmwrrs.ose.state.nm.us/nmwrrs/index.html; accessed July 24, 2012) and from the Colorado Division of Water Resources

(http://water.state.co.us/DataMaps/GISandMaps/AquaMap/Pages/default.aspx; accessed July 24, 2012) database using locations and depth to water for wells with static water levels between 0 and 100 feet (ft) below land surface. Because the geospatial data representing depth to water (D) were developed independently for each State and then merged, there is an abrupt change in depth to water at the border between the States. The type of depth to water information used for New Mexico was dependent on the objectives set forth for that specific study. Without this information it was difficult to duplicate the same type of depth to water data for Colorado. As a result, the geospatial data representing New Mexico and Colorado depth to water are not directly comparable. Depth to water $(D$, in units of feet) was assigned the following DRASTIC index values: 0-5 ft, 10; greater than 5-10 ft, 9; greater than 10-20 ft, 8; greater than 20-30 ft, 7; greater than 30-50 ft, 5; greater than 50-75 ft, 3; greater than 75-100 ft, 2; greater than $100 \mathrm{ft}, 1$.

Recharge $(R)$ was calculated using land use as a surrogate for recharge (Rupert, 1999) by using the national land cover dataset (NLCD) (Vogelmann and others, 2001). Recharge values are listed in table 1 .

Table 1. Recharge $(R)$ values assigned to national land cover dataset (Vogelmann and others, 2001) land-use classifications.

\begin{tabular}{lc}
\hline \multicolumn{1}{c}{ Land cover classification } & R value \\
\hline Open water & 0 \\
Perennial ice/snow & 0 \\
Developed, open space & 3 \\
Developed, low intensity & 3 \\
Developed, medium intensity & 3 \\
Developed, high intensity & 3 \\
Barren land (rock/sand/clay) & 1 \\
Deciduous forest & 1 \\
Evergreen forest & 1 \\
Mixed forest & 1 \\
Shrub/Scrub & 1 \\
Grassland/Herbaceous & 1 \\
Pasture/Hay & 2 \\
Cultivated crops & 2 \\
Woody wetlands & 1 \\
Emergent herbaceous wetlands & 1 \\
\hline
\end{tabular}

The New Mexico Department of Agriculture used the map "Principal Aquifers of the 48 Conterminous United States, Hawaii, Puerto Rico, and the U.S. Virgin Islands"

(http://nationalatlas.gov/mld/aquifrp.html; accessed July 26, 2012) to define aquifer media types for the New Mexico DRASTIC model. The principal aquifer media types in Colorado are the same as those in New Mexico, so the media types for Colorado were assigned index values identical to those used in the DRASTIC model developed by the New Mexico Department of Agriculture. Aquifer media $(A)$ was 
assigned the following DRASTIC index values: unconsolidated sand and gravel aquifers, 8 ; carbonaterock aquifers, 6; sandstone aquifers, 6 ; and other rocks, 4 .

Geospatial data representing soil media were obtained from the State Soil Geographic (STATSGO) database (Natural Resources Conservation Service, 2010). Index values for soil media in Colorado were identical to the index values used in the DRASTIC model developed by the New Mexico Department of Agriculture (2012). Soil media type $(S)$ was assigned the following DRASTIC index values: sand, 9; shrinking and/or aggregated clay, 7; sandy loam, 6; loam, 5; silty loam, 4; clay loam, 3; and nonshrinking and nonaggregated clay, 1 .

The topography factor $(T)$ was calculated from a national elevation dataset (U.S. Geological Survey, 1999) digital elevation model (DEM), specifically, the Elevation Derivatives for National Applications (EDNA) slope model (http://edna.usgs.gov/Edna/edna.asp; accessed July 26, 2012). The topography factor requires slope units in percent. The EDNA slope model (in units of degrees) was converted by using the raster calculator and the equation, $\tan ($ "EDNA_slope"/(180/Pi)). Topography factor values were then assigned values identical to those used in the New Mexico DRASTIC model. Topography (in units of percent) was assigned the following DRASTIC index values: $0-2$ percent, 10 ; greater than 2-6 percent, 9; greater than 6-12 percent, 5; greater than 12-18 percent, 3; and greater than 18 percent, 1.

The index values for impact of the vadose zone were assigned based on the values used by the New Mexico Department of Agriculture (http://river.nmsu.edu/Website/nmda/nmda_website/drastic.html, accessed July 24, 2012), and the spatial extent of the areas to which the index values were assigned were based on the map of Principal Aquifers of the 48 Conterminous United States, Hawaii, Puerto Rico, and the U.S. Virgin Islands (http://nationalatlas.gov/mld/aquifrp.html, accessed July 26, 2012). Impact of the vadose zone (I) was assigned the following DRASTIC index values: unconsolidated sand and gravel aquifers, 8 ; carbonaterock aquifers, 7; sandstone aquifers, 6 ; and other rocks, 4 .

The index values for hydraulic conductivity $(C)$ for Colorado were extrapolated from the hydraulic conductivity map used in the DRASTIC model developed by the New Mexico Department of Agriculture (2012), which assigned hydraulic conductivity index values based on aquifer media. The hydraulic conductivity index values assigned to the New Mexico aquifer media types were assigned to their matching aquifer media types in Colorado. Hydraulic conductivity (in units of gallon-per-day per square feet) was assigned the following DRASTIC index values: unconsolidated sand and gravel aquifers, 2; carbonate-rock aquifers, 10; sandstone aquifers, 1 ; and other rocks, 4 .

The weighting values assigned to the different layers are identical to those used by the New Mexico Department of Agriculture in the development of a DRASTIC model for New Mexico (http://river.nmsu.edu/Website/nmda/nmda_website/drastic.html, accessed July 24, 2012). The following weighting values were assigned to the geospatial layers: depth to water, 5; recharge, 4; aquifer media, 3; soil media, 5; topography, 3; impact of the vadose zone, 4 ; and hydraulic conductivity, 2.

\section{Application of the Model}

The results of the DRASTIC model provide a qualitative interpretation of aquifer vulnerability for Colorado and New Mexico. The model evaluates vulnerability for aquifers within $100 \mathrm{ft}$ of the land surface (Aller and others, 1987). The DRASTIC map as presented in the Energy Atlas is based on generalized data over the two-State area (fig. 1). Because of the resolution of the data used in model development, vulnerability estimates at large scales will likely be more representative than those done at smaller scales. The influence of the abrubt change in the depth to water data at the State border on the vulnerability estimates is evident in figure 1. 
Relative aquifer vulnerability for Colorado and New Mexico as estimated by using the DRASTIC index value is shown in figure 1. The aquifer vulnerability index values as modeled for the two-State area range from 48 to 199. Possible values for the index, given the range of variables used in the model, range from 26 to about 260. Higher values, indicating greater relative aquifer vulnerability, are centered in south-central Colorado, areas in southeastern New Mexico, and along riparian corridors in both States - all areas where the water table is relatively close to the land surface and the aquifer is more susceptible to surface influences. Areas with lower index values correspond to topographic highs and areas where the water table is deeper, indicating that aquifer vulnerability to environmental or anthropogenic inputs from the land surface is reduced relative to areas where the water table is closer to the surface. 


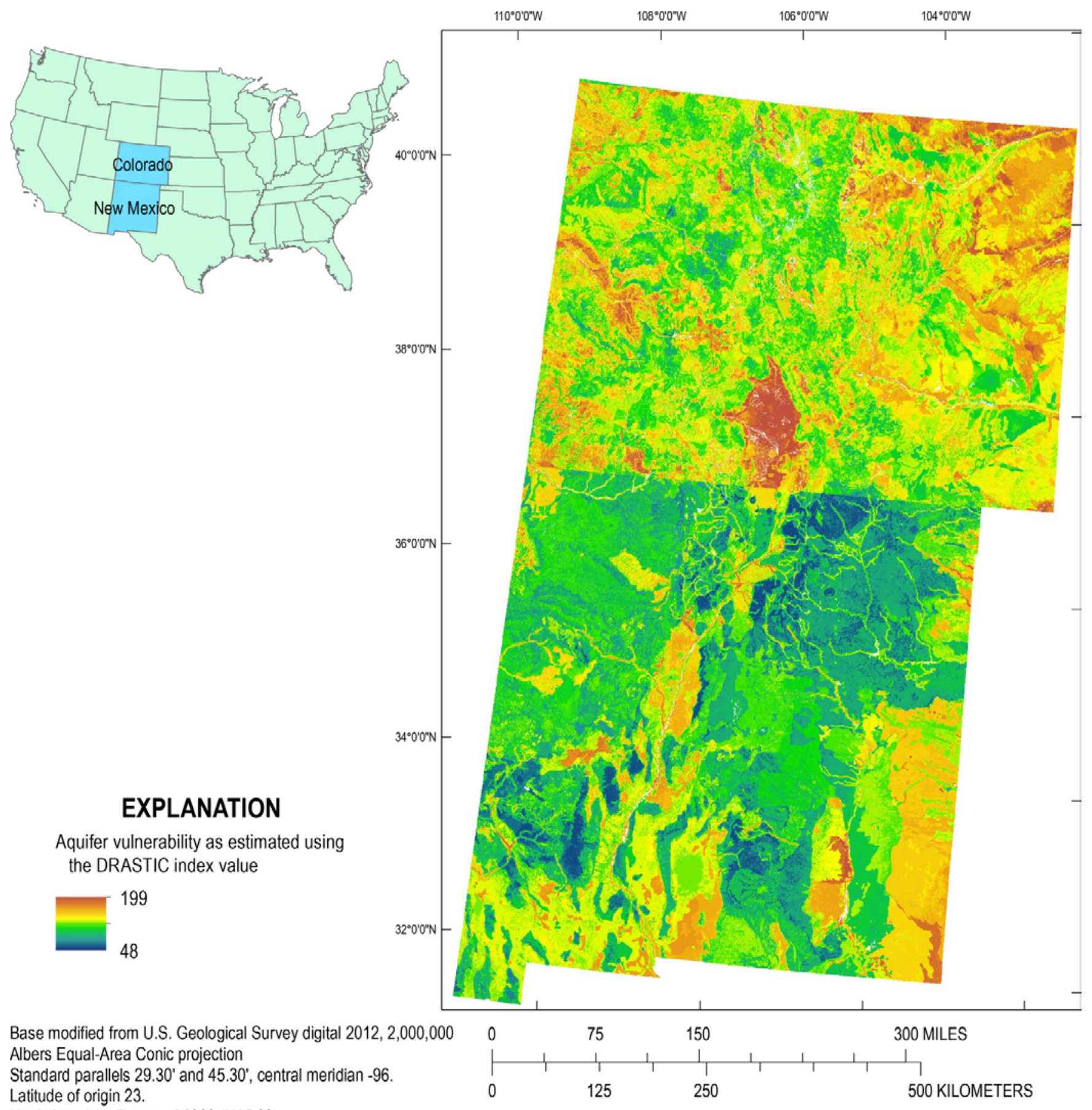

North American Datum of 1983 (NAD83)

Figure 1. Aquifer vulnerability for Colorado and New Mexico as estimated by using the index value from depth to water, recharge, aquifer media, soil media, topography, impact of the vadose zone, and hydraulic conductivity of the aquifer (DRASTIC; Aller and others, 1987). 


\section{Revised Universal Soil Loss Equation}

\section{Model Parameters and Uses and Data Sources}

The Universal Soil Loss Equation (USLE) is an empirical erosion-prediction model originally developed for use on cropland and derived from more than 10,000 plot-years of data (Wischmeier and Smith, 1978). The methodology was extended to broader applications and updated to incorporate refinements in data and technology as the RUSLE (Renard and others, 1997). The model uses parameters representing rainfall energy, soil erodibility, contributing area, vegetation, and erosioncontrol practice. The calculation of mean annual soil loss by RUSLE takes the form of

$$
A=R^{*} K^{*} L S^{*} C^{*} P
$$

where

$A$ is the mean annual soil loss in units of tons per acre per year,

$R$ is the rainfall-energy factor in units of tons per hectare per year (divide $R$ by 17.02 to convert to tons per acre per year),

$K$ is the soil-erodibility factor (unitless),

$L S$ is the slope-length factor (unitless),

$C$ is the vegetative cover factor (unitless), and

$P$ is the erosion-control practice factor (unitless) (Mitasova and Mitas, 1999).

Technological improvements have led to the incorporation of RUSLE into GIS and the ability to estimate erosion potential, as estimated by soil loss, in varied terrain (Mitasova and others; 1996, Miller and others, 2003; Rodriguez and Suarez, 2010). The model has been used to evaluate the effectiveness of landscape management practices (Lopez-Vicente and others, 2011), map areas of high potential postwildfire erosion (Larsen and MacDonald, 2007; Miller and others, 2003), and to delineate locations of active soil loss in potential contaminant source areas (Dai and others, 2012; Trahan, 2002), among other applications.

Geospatial data representing RUSLE parameters were obtained from publicly available sources and applied to an area extending over Colorado and New Mexico. Potential mean annual erosion, as soil loss in tons per acre per year, for Colorado and New Mexico, as estimated by using RUSLE, is shown in figure 2. The geospatial data representing rainfall energy $(R)$ are based on U.S. Department of Agriculture isoerodent maps of the United States published by the U.S. Environmental Protection Agency (2012). The geospatial data representing soil erodibility $(K)$ were obtained from the State Soil Geographic (STATSGO2) database (Natural Resources Conservation Service, 2010). Slope-length factor $(L S)$ was calculated from the 30-meter National Elevation Dataset DEM (U.S. Geological Survey, 1999) and methods described by Mitasova and Mitas (1999). From the DEM, rasters representing slope and flow accumulation were created and used in the equation documented by Mitasova and Mitas (1999): (((flow accumulation raster)* 30/22.1)^Power(0.6))*((((sin(slope raster)*0.01745)/0.09)^Power(1.3)**1.6). Initially, RUSLE was designed for application to hillslopes with lengths less than 1,000 ft and slopes less than 60 percent (Renard and others, 1997). Although infinite slope lengths could exist, the area comprising the hillslope should have minimal areas of deposition or channelized flow (either natural or constructed) (Renard and others, 1997). For these reasons, $L S$ values were not allowed to exceed 72.15, which is the maximum value reported by Renard and others (1997). The vegetative cover factor $(C)$ was determined by using the NLCD (Vogelmann and others, 2001) and associated coefficients that ranged from 0.001 to 0.004 based on descriptions by Wischmeier and Smith (1978). The following are the assigned vegetative cover factors: open water, null; perennial ice/snow, null; developed, open space, 0.03; developed, low intensity, 0.03; developed, medium intensity, 0.03; developed, high intensity, 0.03; barren land, 0.05; deciduous forest, 0.002 ; 
evergreen forest, 0.002; mixed forest, 0.002; shrub/scrub, 0.04; grassland/herbaceous, 0.01; pasture/hay, 0.003; cultivated crops, 0.04; woody wetlands, 0.001 ; and emergent herbaceous wetland, 0.001 . The erosion-control practice factor $(P)$ was set to 1.0 (no conservation treatment) because the model is designed to represent an undeveloped condition.

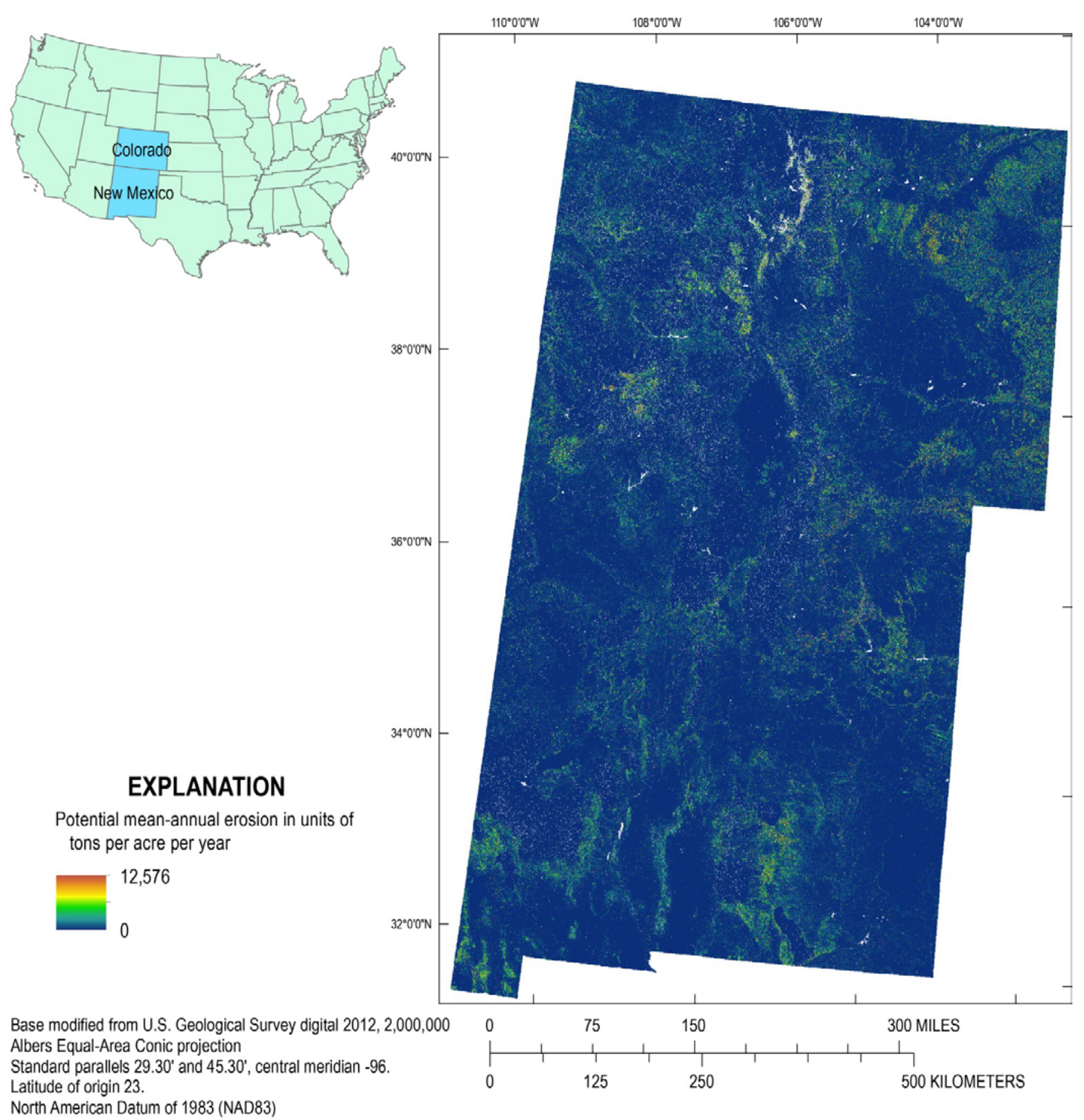

Figure 2. Potential mean annual erosion for Colorado and New Mexico as estimated by using the revised universal soil loss equation (RUSLE) (Renard and others, 1997). 


\section{Application of the Model}

Deposition and channel erosion are not modeled by the RUSLE method, and therefore RUSLE does not model sediment yields at watershed and broader scales; rather, the model approximates the amount of potential soil loss (Wischmeier, 1976). The mean annual erosion potential maps for Colorado and New Mexico represent a generalized assessment over the two-State area. The rainfall-energy factor $(R)$ was developed by Renard and others (1997), and many precipitation stations have been added across the United States since its development. Updating the rainfall-energy factor by using an expanded precipitation network was outside the scope of this study. The STATSGO soils data used for the soilerodibility factor $(K)$ in the analysis are at a small scale of 1:250,000 (Natural Resources Conservation Service, 2010) but were selected because the data covered the full spatial extent of the study area. In order to minimize calculation of soil loss for pixels with the potential for deposition or channel erosion, the slope-length factor ( $L S$, unitless) was limited to values less than 72.15 , following the value as reported by Renard and others (1997). Cells representing a slope-length factor greater than 72.15, where estimates of erosion potential were not calculated, generally correspond to channels or to topographic lows representing depositional zones and so are not modeled by RUSLE. Vegetative cover factors $(C)$ were uniformly applied for a given land-use classification regardless of the variability that could be imposed by accounting for vegetation density, surface cover, surface roughness, and soil moisture. Given the annual time scale of the map, these $C$ values were assigned as constants following assumptions detailed by Renard and others (1997).

Within the limitations noted, erosion potential can be estimated as an average over watershed scales of about 2-20 square miles $\left(\mathrm{mi}^{2}\right)$, which is similar to the work of Miller and others (2003). To estimate mean potential soil loss, the user should average the 30-meter-resolution pixel values for the area of interest and then multiply by the area, converting from acres to the units of area desired.

Potential mean annual erosion for Colorado and New Mexico as estimated by using the RUSLE method is shown in figure 2. Potential soil loss, in units of tons per acre per year, ranges from 0 to almost 12,600 over the two-State area. The RUSLE model calculated low erosion potential over most of Colorado and New Mexico, with predictions of highest erosion potential largely confined to areas of mountains or escarpments. Estimates of soil loss using the RUSLE method are best considered as a relative index to compare areas with greater or less erosion potential rather than as a quantitative indicator of soil loss.

\section{Example-Using the RUSLE Model to Explore Potential Effects of Energy Development on Hydrologic Resources}

Both the DRASTIC and RUSLE models as incorporated into the Energy Atlas are static maps representing generalized conditions over Colorado and New Mexico. These maps may be combined with the interactive maps and data layers included in the Energy Atlas to assess the location of present or proposed energy development with respect to aquifer vulnerability or erosion potential. An example of how a fully interactive RUSLE model could be used as a decision-support tool to evaluate the potential hydrologic effects of energy development on a site-specific basis and to explore the effectiveness of various mitigation practices is presented in figure 3 .

Figure $3 A$ represents a hypothetical study area including several representative surface features. Highlighted areas represent locations containing oil and gas wells, roads, and a road running along a stream. Figure $3 B$ represents a generalized topography for the same area showing relative contour lines, roads as black lines, and waterways as blue lines. Figure $3 C$ demonstrates how the effect of varying vegetative cover and erosion-control practices could be explored with the RUSLE model by showing 
relative changes in predicted erosion for the three types of surface features highlighted in figure $3 \mathrm{~A}$, under four land-surface conditions. Of the five parameters included in the RUSLE model (eq. 2), the two parameters demonstrated are $C$ (vegetative cover) and $P$ (erosion-control practice). For the condition of no development, $C$ ranges between 0.002 and 0.05 , depending on land use, and $P$ is set equal to zero. For the three developed conditions, $C$ is set uniformly to 0.2 , and $P$ is varied for each of the three conditions as 0.1 (seeded and sediment detention pond), 0.18 (seeded and rough surface), and 0.26 (seeded and scraped smooth), and compares the susceptibility to erosion for each of the three erosion-control practices for a given vegetative cover. For a given cover value $(C)$, soil loss $(A)$ increases with increasing erosion-control practice $(P)$. Areas with higher values for the soil erosivity $(K)$ and slope-length $(L S)$ factors within the area modeled are more sensitive to adjustments to $C$ and $P$ factors (Renard and others, 1991) as indicated by the increase in potential soil loss between scenarios. Thus, in this example, a road coincident with a stream is modeled as having a higher erosion potential than one that runs along the hillslope (fig. $3 \mathrm{C}$ ). The edges of well pads are also modeled as locations of high erosion potential.

The RUSLE model does not account for deposition and storage along an erosion pathway and does not model connectivity or lack of connectivity between components of development or mitigation strategies. The model can be used, however, to identify areas of high erosion potential and to explore the effectiveness of various cover types and erosion-control practices. Results from the RUSLE model, in conjunction with other maps and data layers included in the Energy Atlas, can support decison-makers in anticipating and minimizing the surface effects of potential energy development. 

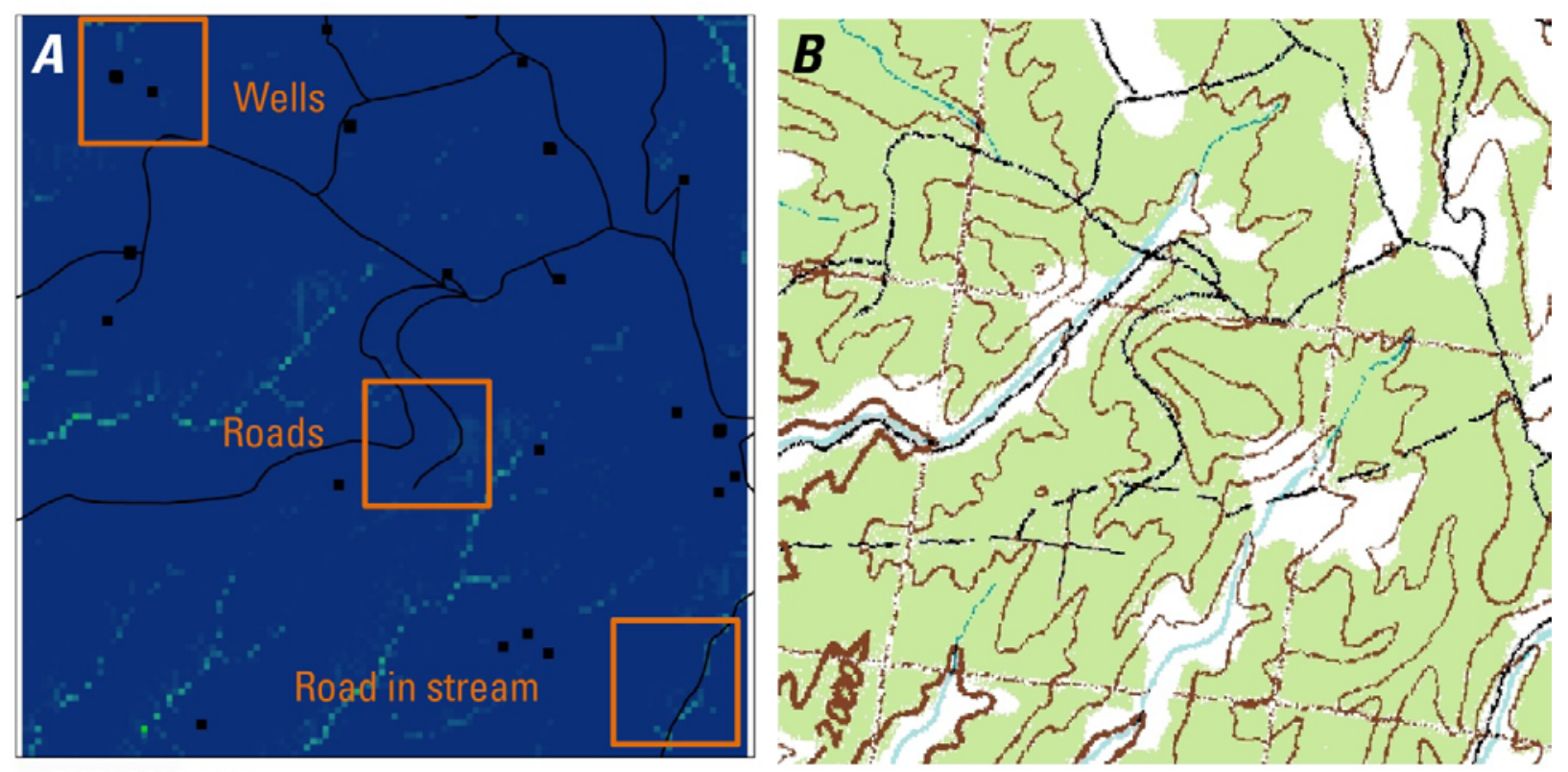

\section{EXPLANATION}

Relative erosion potential

6

- Access roads

- Oil \& gas wells

$\begin{array}{lll}0 & 0.2 & 0.4\end{array}$ 0.8 Miles

C Parameters

Wells

Roads

Road in stream

No development

( $C=0.002-0.05$ depending on land use, $P=0$ )
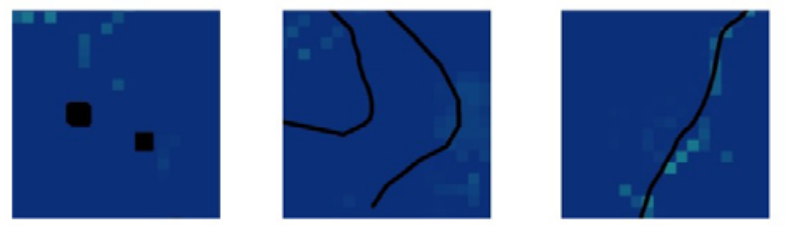

Developed, seeded, sediment detention pond

$(C=0.2, P=0.1)$
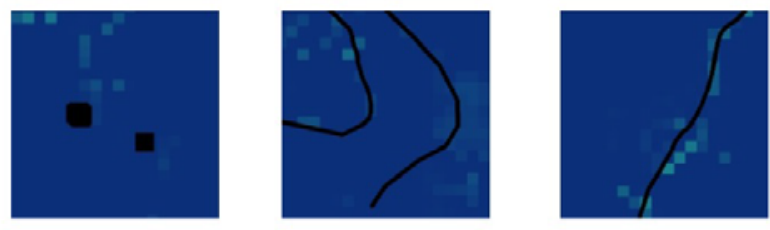

Developed, seeded, rough surface $(C=0.2, P=0.18)$
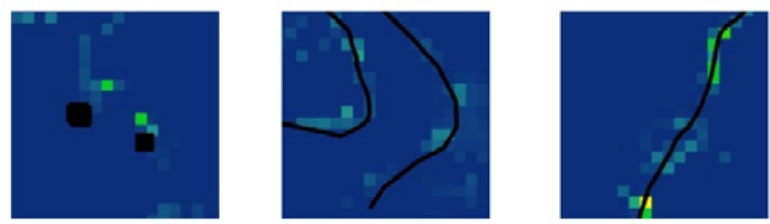

Developed, seeded, scraped smooth $(C=0.2, P=0.26)$
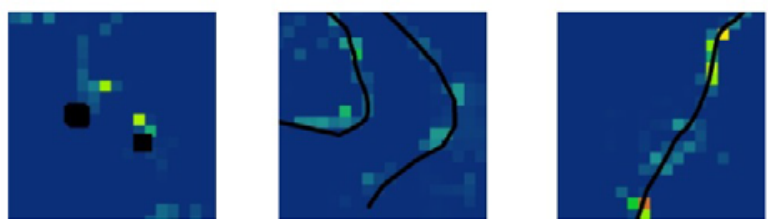

Figure 3. Examples of the use of the revised universal soil loss equation (RUSLE) model as a hydrologic decision-support tool, comparing three landscape features under three scenarios of vegetative cover $(C)$ and 
four scenarios of erosion-control practice $(P)$. $A$, Hypothetical study area including representative surface features. $B$, Generalized topography for the hypothetical study area. $C$, Relative changes in erosion potential for three types of surface features under four land-surface conditions. As the $C$ or $P$ value increases, model cells for which relative erosion potential increases are shown by a change in cell color.

\section{Summary}

Increased demand for energy is driving rapid development of energy sources throughout the Western United States, including oil and gas, uranium, geothermal, wind, and solar energy. Much of the energy development is occurring on public lands, which represent about 40 percent of land ownership in Colorado and New Mexico. The U.S. Geological Survey project-Energy and Environment in the Rocky Mountain Area (EERMA) - has developed a set of virtual tools in the form of an online interactive energy atlas (Energy Atlas) for Colorado and New Mexico to facilitate access to geospatial data related to energy resources, energy infrastructure, and natural resources that may be affected by energy development. The Energy Atlas consists of three components: (1) a series of interactive maps; (2) downloadable geospatial datasets; and (3) decison-support tools, including two maps, related to hydrologic resources discussed in this report. The report presents two geospatial datasets-aquifer vulnerability and potential mean annual erosion — which are part of the Energy Atlas decision-support tools.

The hydrologic decision-support tools in the Energy Atlas focus on groundwater and surfacewater quality. The potential effects of energy development on groundwater quality are explored by using (1) the aquifer vulnerability model: depth to water, recharge, aquifer media, soil media, topography, impact of the vadose zone, and hydraulic conductivity of the aquifer (DRASTIC); and (2) potential effects on surface-water quality are explored by using the revised universal soil loss equation (RUSLE).

DRASTIC was developed for the Colorado-New Mexico area to examine the potential susceptibility of groundwater aquifers to conservatively transported constituents, which may be present as a result of some types of energy development. Spatial analysis based on RUSLE was used to map relative differences in erosion potential over the Colorado-New Mexico area to examine possible changes in erosion potential with changes in land use and cover. Spatial analysis based on the RUSLE model can point to areas of concern as potential sources of sediment input to waterways, aiding in focusing management efforts.

DRASTIC methodologies and selected index and weighting values for both Colorado and New Mexico follow the DRASTIC model developed by the New Mexico Department of Agriculture in 2012 for the State of New Mexico. Geospatical data representing DRASTIC model parameters were from publicly available sources. The aquifer vulnerability index value for the two-State area ranges from 48 to 199 . Higher values, indicating greater relative aquifer vulnerability, are centered in south-central Colorado, areas in southeastern New Mexico, and along riparian corridors in both States - all areas where the water table is relatively close to the land surface, and the aquifer is more susceptible to surface influences.

The RUSLE model uses parameters representing rainfall energy, soil erodibility, contributing area, vegetation, and erosion-control practices. Geospatial data representing RUSLE parameters were obtained from publicly available sources and applied to an area extending over Colorado and New Mexico. Potential mean annual erosion, as soil loss in units of tons per acre per year, ranges from 0 to about 12,600 over the two-State area. The RUSLE model calculated low erosion potential over most of Colorado and New Mexico, with predictions of highest erosion potential largely confined to areas of mountains or escarpments. Estimates of soil loss using the RUSLE method are best considered as a 
relative index to compare areas with greater or less erosion potential rather than as a quantitative indicator of soil loss.

DRASTIC and RUSLE as incorporated into the interactive energy atlas are static maps representing generalized conditions over Colorado and New Mexico. An example was presented of how a fully interactive RUSLE model could be further used as a decision-support tool to evaluate the potential hydrologic effects of energy development on a site-specific basis and to explore the effectiveness of various mitigation practices.

\section{References Cited}

Aller, L., Bennett, T., Lehr, J.H., Petty, R.J., and Hackett, G., 1987, DRASTIC-A standardized system for evaluating ground water pollution potential using hydrogeologic settings: National Water Well Association/Environmental Protection Agency series, EPA-600/2-87-035.

Babiker, I.S., Mohamed, M.A.A., Hiyama, Tetsuya, and Kato, Kikuo, 2005, A GIS-based DRASTIC model for assessing aquifer vulnerability in Kakamigahara Heights, Gifu Prefecture, central Japan: Science of the Total Environment, v. 345, p. 127-140.

Copeland, H.E., Pocewicz, A., and Kiesecker, J.M., 2011, Geography of energy development in Western North America-Potential impacts to terrestrial ecosystems, in Naugle, D.E., ed., Energy development and wildlife conservation in Western North America: Washington, D.C., Island Press, p. 7-22.

Dai, Z-h., Feng, X.-b., Zhang, C., Qiu, G.-I., and Shang, L.-h., 2012, Surface soil mercury translocation in Wanshan mercury mining area of southwest China: Chinese Journal of Ecology, v. 31, no. 8, p. 2103-2111.

Gregory, K.B., Vidic, R.D., and Dzombak, D.A., 2011, Water management challenges associated with the production of shale gas by hydraulic fracturing: Elements, v. 7, p. 181-186.

Grubert, E.A., Beach, F.C., and Webber, M.E., 2012, Can switching fuels save water? A life cycle quantification of freshwater consumption for Texas coal- and natural gas-fired electricity: Environmental Research Letters, v. 7, 11 p., accessed November 13, 2012, at http://iopscience.iop.org/1748-9326/7/4/045801.

Headwaters Economics, 2012a, Report-Colorado's oil and gas industry: Headwaters Economics Web site, accessed June 6, 2013, at http://headwaterseconomics.org/energy/western/colorado-oil-and-gas/. Headwaters Economics, 2012b, Report-New Mexico's oil and gas industry: Headwaters Economics Web site, accessed June 6, 2013, at http://headwaterseconomics.org/energy/western/ new-mexico-oil-and-gas/.

Hearne, G.A., Wireman, Michael, Campbell, A.S., Turner, Sandy, Ingersoll, G.P., 1995, Vulnerability of the uppermost ground water to contamination in the greater Denver area, Colorado: U.S. Geological Survey Water-Resources Investigations Report 92-4143, 244 p.

Kenny, J.F., Barber, N.L., Hutson, S.S., Linsey, K.S., Lovelace, J.K., and Maupin, M.A., 2009, Estimated use of water in the United States in 2005: U.S. Geological Survey Circular 1344, 52 p. Larsen, I.J., and MacDonald, L.H., 2007, Predicting post-fire sediment yields at the hillslope scaleTesting RUSLE and disturbed WEPP: Water Resources Research, v. 43, no. 11, article no. W11412, $8 \mathrm{p}$.

Loesch, C.R., Walker, J.A., Reynolds, R.E., Gleason, J.S., Niemuth, N.D., Stephens, S.E., and Erickson, M.A., 2012, Effect of wind energy development on breeding duck densities in the Prairie Pothole Region: The Journal of Wildlife Management, DOI: 10.1002/jwmg.481, 12 p., accessed February 6, 2012, at http://onlinelibrary.wiley.com/doi/10.1002/jwmg.481/pdf. 
Lopez-Vicente, M., Lana-Renault, N., García-Ruiz, J.M., and Navas, A., 2011, Assessing the potential effect of different land cover management practices on sediment yield from an abandoned farmland catchment in the Spanish Pyrenees: Journal of Soils and Sediment, v. 11, no. 8, p. 1440-1455.

Miller, J.D., Nyhan, J.W., and Yool, S.R., 2003, Modeling potential erosion due to the Cerro Grande fire with a GIS-based implementation of the revised universal soil loss equation: International Journal of Wildland Fire, v. 12, p. 85-100.

Mitasova, Helena, and Mitas, Lubos, 1999, Modeling soil detachment with RUSLE 3d using GIS: Geographic Modeling Systems Laboratory, University of Illinois at Urbana-Champaign, accessed June 11, 2014, at http://www4.ncsu.edu/ hmitaso/gmslab/erosion/usle.html.

Mitasova, H., Hofierka, J., Zlocha, M., and Iverson, L.R., 1996, Modeling topographic potential for erosion and deposition using GIS: International Journal of Geographical Information Science, v. 10, no. 5, p. 629-641.

Natural Resources Conservation Service, 2010, U.S. general soil map (STATSGO2): U.S. Department of Agriculture, accessed August 3, 2010, at http://websoilsurvey.sc.egov.usda.gov/App/HomePage.htm.

Nearing, M.A., Jetten, V., Baffaut, C., Cerdan, O., Couturier, A., Hernandez, M., Le Bissonnais, Y., Nichols, M.H., Nunes, J.P., Renschler, C.S., Souchère, V., and van Oost, K., 2005, Modeling response of soil erosion and runoff to changes in precipitation and cover: Catena, v. 61, p. 131-154.

New Mexico Department of Agriculture, 2012, NMDA DRASTIC interactive mapping applications: New Mexico Department of Agriculture Web site, accessed August 18, 2014, at http://river.nmsu.edu/Website/nmda/nmda_website/drastic.html.

Prosser, I.P., and Williams, Lisa, 1998, The effect of wildfire on runoff and erosion in native Eucalyptus forest: Hydrological Processes, v. 12, p. 251-265.

Rahman, Atiqur, 2008, A GIS based DRASTIC model for assessing groundwater vulnerability in shallow aquifer in Aligarh, India: Applied Geography, v. 28, p. 32-53.

Ren, Sheng-ming; Liang, Yin; and Sun, Bo, 2011, Quantitative analysis on the influence of long-term soil and water conservation measures harnessing on runoff and sediment yield of watershed: Procedia Environmental Sciences, v. 10, p. 1732-1740.

Renard, K.G., Foster, G.R., Weesies, G.A., McCool, D.K., and Yoder, D.C., 1997, Predicting soil erosion by water-A guide to conservation planning with the revised universal soil loss equation (RUSLE): Washington, D.C., U.S. Department of Agriculture Handbook No. 703, 384 p.

Renard, K.G., Foster, G.R., Weesies, G.A., and Porter, J.P., 1991, RUSLE revised universal soil loss equation: Journal of Soil and Water Conservation, v. 46, no. 1, p. 30-33.

Rodriguez, J.L.G., and Suarez, M.C.G., 2010, Estimation of slope length value of RUSLE L using GIS: Journal of Hydrologic Engineering, v. 15, no. 9, p. 714-717.

Rupert, M.G., 1999, Improvements to the DRASTIC ground-water vulnerability mapping method: U.S. Geological Survey Fact Sheet FS-066-99, 6 p., available at http://pubs.er.usgs.gov/publication/fs06699.

Shirazi, S.M., Imran, H.M., and Akib, S., 2012, GIS-based DRASTIC method for groundwater vulnerability assessment-A review: Journal of Risk Research, v. 15, no. 8, p. 991-1011.

Trahan, Nadine, 2002, Modeling sediment and contaminant pathways to the Cedar River: 22d Annual Esri International User Conference, July 8-12, 2002, accessed September 12, 2012, at http://proceedings.esri.com/library/userconf/proc02/pap0785/p0785.htm.

U.S. Environmental Protection Agency, 2012, Storm water phase II final rule - Construction rainfall erosivity waiver: U.S. Environmental Protection Agency Stormwater Phase II Final Rule Fact Sheet 
3.1, EPA 833-F-00-014, 12 p., accessed September 27, 2012, at http://www.epa.gov/npdes/pubs/ fact3-1.pdf.

U.S. Geological Survey, 1999, National elevation dataset: U.S. Geological Survey Fact Sheet 148-99, $2 \mathrm{p}$.

Vogelmann, J.E., Howard, S.M., Yang, L., Larson, C.L., Wylie, B.K., and Van Driel, N., 2001, Completion of the 1990s national land cover data set for the conterminous United States from Landsat Thematic Mapper data and ancillary data sources: Photogrammetric Engineering and Remote Sensing, v. 67 , p. $650-652$.

Voudouris, N., Kazakis, M., Polemio, M., and Kereklas, K., 2010, Assessment of intrinsic vulnerability using the DRASTIC model and GIS in the Kiti aquifer, Cyprus: European Water, v. 30, p. 13-24.

Warner, N.R., Jackson, R.B., Darrah, T.H., Osborn, S.G., Down, Adrian, Zhao, Kaiguang, White, Alissa, and Vengosh, Avner, 2012, Geochemical evidence for possible natural migration of Marcellus Formation brine to shallow aquifers in Pennsylvania: Proceedings of the National Academy of Sciences, v. 109, no. 30, p. 11961-11966.

Wischmeier, W.H., 1976, Use and misuse of the universal soil loss equation: Journal of Soil and Water Conservation, v. 31, p. 5-9.

Wischmeier, W.H., and Smith, D.D., 1978, Predicting rainfall erosion losses-A guide to conservation planning: Washington, D.C., U.S. Department of Agriculture Handbook No. 537, 63 p. 